\title{
KHALAYAK MEDIA BARU
}

\author{
Ruth Mei Ulina Malau \\ (ruthmeimalau@gmail.com) \\ Peneliti New Media
}

\begin{abstract}
New media era brought a complex story about what is media audience nowadays. The situasion in this postmodernism world is quite different because audience has become more active in consuming the new media. The one that once known as mass audience has now dissapeared because of the popularity of the new media. When audience is no longer a mass, fandom emerge as one of the most known as the new media audience.
\end{abstract}

Keywords: audience, new media, mass, fandom.

\section{PENDAHULUAN}

Khalayak media didefinisikan secara berbeda, tergantung pada medium yang digunakan dan perspektif yang diadopsi. Dalam era setelah modernisme, seiring dengan munculnya media baru (new media), terjadi perubahan bentuk khalayak media. Khalayak media lama menjadi kabur atau bahkan seolah-olah menghilang. Media baru tidak hanya menciptakan bentuk-bentuk model komunikasi baru, namun juga menciptakan khayalak baru. Bentukbentuk khalayak media baru perlu dikaji ulang karena akan sangat bermanfaat bagi perencanaan media massa di masa depan.

\section{PEMBAHASAN}

\section{Tipologi Khalayak}

Pandangan awal tentang khalayak, seperti dikemukakan oleh Wilbur Lang Schramm, menyebutkan bahwa khalayak merupakan kumpulan receiver yang merupakan bagian dari model sederhana proses komunikasi massa (source, channel, message, receiver, effect). Khalayak merupakan kumpulan receiver yang merupakan bagian dari model sederhana proses komunikasi massa (source, channel, message, receiver, effect) (Schramm, 1955). Khalayak bisa didefinisikan dengan berbagai cara, salah satunya menurut Nightingale (2003), yang membagi khalayak ke dalam 4 tipologi:

(a) Audience as 'the people assembled', khalayak jenis ini disebut penonton, yaitu kelompok orang yang memberi perhatian terhadap produk media pada waktu tertentu;

(b) Audience as 'the people addresed', mengacu pada khalayak sasaran yang diimaginasikan oleh media;

(c) Audience as 'happening', mengacu pada pengalaman interaktif dengan orang lain yang terkontekstualisasikan tempat dan hal-hal lain;

(d) Audience as 'hearing' or 'audition', mengacu pada khalayak partisipatoris yang terlibat dalam program acara media.

Herbert Blummer (1939) memberikan kerangka pemikiran yang eksplisit di mana khalayak dapat dicontohkan sebagai bentuk kolektifitas baru dimungkinkan oleh kondisi kehidupan masyarakat modern. Dia menyebut fenomena ini sebagai 'mass' dan dibedakan dari bentuk sosial yang lama seperti kelompok, kerumunan dan publik. Khalayak massa sangat besar, heterogen, dan tersebar luas, dan masing-masing anggotanya tidak dan mungkin tidak saling mengenal satu sama lain. Pandangan khalayak massa ini merefleksikan pandangan negatif 
terhadap selera populer dan budaya massa (McQuail, 2010: 398,400).

\section{Media dan Postmodernisme}

Televisi merupakan salah satu media yang sangat powerfull di masa modernisme, yang diasumsikan mengartikan khalayak media dalam istilah 'massa'. Namun selanjutnya, hadirnya postmodernisme telah mengubah pandangan tentang khalayak media, terutama khalayak televisi (Ang, 1996: 1). Massa hanya sepenggal konstruksi sejarah yang diwariskan oleh modernisme. Hal ini sejalan dengan pernyataan Benedict Anderson (1983) tentang bangsa sebagai imagined community di mana massa dalam hal ini juga dilihat sebagai komunitas yang terbentuk dari hasil imajinasi media. Khalayak media merupakan komunitas imajinasi yang diorganisir oleh media sebagai massa.

"Selama rakyat diorganisir...sebagai massa, mereka kehilangan identitas dan kualitas sebagai manusia. Karena massa, dalam kerangka waktu historis adalah kerumunan di dalam ruang: orang dalam jumlah besar yang tidak mampu mengekspresikan dirinya sebagai umat manusia karena mereka terkait satu sama lain bukan sebagai individu atau anggota masyarakat--sebenarnya mereka tidak terkait satu sama lain, kecuali untuk hubungan yang berjarak, abstrak, dan manusiawi...Manusia massa adalah sebuah atom soliter, seragam, dan tidak bisa dibedakan dari ribuan maupun jutaan atom lain yang menyusun "kerumunan kesepian"..." MacDonald (1957) dikutip dari Strinati (2009: 40).

Tafsiran mengenai khalayak media selalu menjadi ambiguitas yang sulit dipahami (Tester, 2009: 120), terutama ketika postmodernisme mulai mempertanyakan keberadaan massa. Sama seperti yang diungkapkan oleh Raymond Williams, "there are in fact no masses". Istilah tersebut hanya sekedar cara pandang manusia yang melihat manusia sebagai 'massa' (Ross \& Nightingale, 2003: vii). Massa bukan sekedar sebuah obyek penelitian yang secara natural telah ada, tapi massa harus didefenisikan dan dikonstruksikan setiap saat terkait dengan penggunaan media/konsumsi media (Ang, 1996: 3).

Berubahnya pandangan tentang khalayak media dalam dunia postmodern, tidak bisa dilepaskan dari hadirnya sebuah ilmu interdisipliner yang disebut cultural studies. Cultural studies (Sociocultural Approach), merupakan studi tentang media yang membahas isu-isu mengenai budaya pop, konsumerisme, seksualitas, maskulinitas, identitas dan lain-lain. Saat ini cultural studies banyak terfokus pada bagaimana dunia saat ini dikonstruksikan secara sosial dalam tema tertentu yaitu mengenai 'perbedaan' dan identitas. Dalam hal ini, cultural studies bisa dipahami sebagai kajian yang mengeksplorasi budaya, yang di dalamnya terdapat makna dan representasi yang dihasilkan oleh praktek tanda, dalam konteks yang berhubungan dengan relasi kekuasaan dan konsekuensi politik (Barker, 2004: 43). Adorno menyebutkan ketika budaya massa (produk budaya pop yang ditawarkan oleh media) telah menjadi salah satu tontonan, maka semua orang yang jatuh ke dalamnya akan merasa kesepian seperti orang asing di sebuah tempat pertunjukan (Tester, 2009: 73).

Salah satu tokoh Cultural studies, Stuart Hall, memandang media sebagai alat hegemoni kekuasaan. Kajian Hall berfokus pada bagaimana meningkatkan kesadaran masyarakat terhadap peran media dalam mempertahankan status quo. Beberapa tokoh cultural studies, Adorno, Horkheimer, dan Richard Hoggart samasama menegaskan bahwa media telah menciptakan audien budaya virtual yang bodoh dan tidak mampu memberikan respons terhadap berbagai produk dan aktivitas budaya yang tidak ditoleransi 
dan tidak distandarisasikan oleh industri budaya (Tester, 2009: 121).

Ang menyebutkan bahwa perubahan modernisme menjadi postmodernisme, dalam kaitan munculnya cultural studies membuat khalayak media yang ...conventionally conceived as 'watching', 'using', 'receiving', 'consuming', 'decoding', and so on, although these term too already abstractions from the complexity and the dynamism of the social, cultural, psychological, political and historical activities that are involved in people's engagements with television (Ang, 1996: 3). Perubahan pemahaman mengenai khalayak, dari masa modernisme hingga postmoderisme terlihat sangat jelas terutama dalam media televisi. Media lainnya, terutama dengan hadirnya new media, menjadi sebuah ranah baru bagi perkembangan khalayak.

Rogers (1986) menguraikan tiga ciri utama yang menandai kehadiran teknologi komunikasi baru, yaitu: interactivity, demassification, dan asynchronous. Interacticity merupakan kemampuan sistem komunikasi baru untuk berbicara balik, talk back, kepada penggunanya, hampir seperti seorang individu yang berpartisipasi dalam sebuah percakapan. Dalam ungkapan yang lain, media baru memiliki sifat interaktif yang tingkatannya mendekati sifat interaktif pada komunikasi antarpribadi secara tatap muka. Media komunikasi yang interaktif ini memungkinkan para partisipannya dapat berkomunikasi secara lebih akurat, lebih efektif dan lebih memuaskan. Demassification berarti tidak bersifat massal, maksudnya suatu pesan khusus dapat dipertukarkan secara individual di antara partisipan yang terlibat dalam jumlah yang besar. Demassification juga bermakna bahwa kontrol atau pengendalian sistem komunikasi massa biasanya berpindah dari produsen pesan ke konsumen media. Asynchronous bermakna bahwa teknologi komunikasi baru mempunyai kemampuan untuk mengirimkan dan menerima pesan pada waktu-waktu yang dikehendaki oleh setiap individu peserta (Rahardjo, 2011: 7-8).

Kehadiran new media menawarkan speed and space, di mana new media membuka peluang bagi kehadiran informasi-informasi yang tidak dapat ditemukan dalam bentuk hard copy media konvensional. Format multimedia yang ditawarkan juga lebih inovatif dan lebih menarik (Fenton, 2010: 7). Hadirnya new media juga menciptakan peluang digitalisasi budaya, di mana budaya pop menjadi lebih mudah dikonsumsi dengan keberadaan new media yang berbasis internet ini.

Hadirnya new media memperluas pengaruh budaya pop yang dulu hanya dapat diakses melalui media konvensional. Budaya pop ini, seperti yang disebutkan di atas, merupakan warisan dari kajian kritis cultural studies yang digagasi oleh Theodor Adorno dan Max Horkheimer yang menyatakan bahwa budaya pop adalah sebuah "industri budaya" (Stokes, 2003: 116). Industri budaya yang dimaksud bisa ditujukan pada produk budaya domestik tertentu yang diproduksi untuk dikonsumsi secara massal. Indonesia sendiri, dilihat dari sejarahnya, telah mengenal berbagai jenis budaya pop mulai dari budaya pop Barat (musik rock, pop, film Hollywood), budaya pop India (Bollywood), budaya pop Amerika Latin (Telenovela), budaya pop Jepang (Manga, Anime, dan seterusnya), dan saat ini Indonesia sedang rajin mengimpor budaya pop Hallyu (Hallyu merupakan fenomena yang mengacu pada popularitas dan globalisasi budaya pop Korea Selatan).

\section{Media Fandom}

Hadirnya new media dengan berbagai bentuk budaya pop di atas memperkenalkan sebuah komunitas khalayak baru yang berbeda dengan massa, yaitu fandom (media fandom). 
Khalayak media terhubung dengan sumber media yang "jauh" dengan berbagai cara yang relevan dengan institusionalisasi fandom, meskipun hal ini tidak berlangsung secara spontan dan dimanipulasi oleh media. Fandom seringkali diasosiasikan dengan pandangan kritis mengenai ketidakdewasaan, ketidakrasionalan, yang merupakan produk budaya massa dan merupakan contoh perilaku massa. Fandom merupakan sesuatu yang bersifat kolektif, yaitu berbagi perasaan terhadap ketertarikan yang kuat yang dilakukan secara sadar (McQuail, 2010: 442).

Fandom adalah sebuah gaya hidup yang bisa muncul ketika identitas budaya yang berbeda dibenturkan dan identitas budaya yang satu menjadi dominan atas budaya yang lain (Hills, 2002: 82). Di dalam kamus Oxford, fandom diartikan sebagai "the world of fans and enthusiasts..." (The Concise Oxford Dictionary of Current English 487, $9^{\text {th }} e d$, 1995). Entusiasme dalam hal ini membentuk sebuah unsur fanatisme, '...fanaticism is 'enthusiasm for the abstract' (Hegel, dalam Toscano, __: xi). Di dalam dunia fandom yang penuh entusiasme ini, terdapat fanatisme yang menurut Toscano merupakan sebuah efek dari kesadaran yang salah yang mengorbankan banyak hal dan memperbudak kepercayaan terhadap sesuatu yang sangat digemari. Fandom berkembang dari fans, ketika mereka mulai mengasosiasikan diri mereka satu sama lain dan mengekspresikannya dengan cara-cara umum seperti T-shirt, gaya baju, dan lain-lain (McQuail, 2010: 443). Fans (atau penggemar; biasanya dikaitkan dengan generasi muda) adalah seseorang yang terobsesi dengan artis tertentu, selebriti, film, program TV, band. Fans adalah seseorang yang dapat memproduksi banyak sekali informasi tentang objek fandom mereka, dan biasanya mengutip kata-kata dan lirik favorit mereka (Hills, 2002: ix).

New media menciptakan ruang baru bagi perkembangan komunitas-komunitas fandom yang kebanyakan berbasis di internet. Misalnya, di Indonesia kini sedang marak berbagai kelompok fandom Korea (K-fandom), yaitu kelompokkelompok fans yang objek fandomnya adalah budaya pop Korea terutama musik Korea (yang biasa disebut K-pop) dan drama Korea (K-drama). Nama fandom biasanya disesuaikan dengan objek fandom, seperti Star Wars fandom atau Harry Potter fandom. Terkait dengan budaya pop Korea yang sedang melanda, Indonesia melahirkan fandom-fandom seperti ELF, Cassiopeia, VIP, dan sebagainya. Mereka (fandom) merupakan kelompok subkultur yang terbentuk atas dasar passion yang sama terhadap sesuatu yang bisa dikatakan abstrak. Fandom ini merupakan salah satu bentuk baru khalayak media yang semakin berkembang setelah munculnya new media dalam dunia postmodernisme, di mana hubungan yang terjalin antara khalayak dan media tidak lagi diasumsikan sama dengan media lama namun tercipta hubungan imajiner yang mengindikasikan adanya kegilaan khalayak terhadap produk budaya yang merupakan objek fandom mereka.

\section{Computer Mediated Communication}

Di sisi lain, new media merupakan cultural technology yang pada akhirnya menciptakan budaya virtual yang melahirkan komunitas-komunitas virtual dengan identitas online. Menurut Terry Flew (2004: 61-67), salah satu elemen menarik dalam perkembangan internet adalah munculnya komunitas virtual, atau budaya virtual, yang berbasis pada interaksi CMC (computer mediated communication). Hadirnya CMC, mempelopori munculnya konvergensi media tidak hanya di level teknis, 
melainkan juga di level sosial, termasuk perubahan dalam hal:

- Sender dan receiver;

- Percakapan dan informasi;

- Makna yang dibawa;

- Identitas publik dan pribadi.

Budaya menggunakan internet, yang ditawarkan oleh new media memunculkan berbagai kajian komunitas virtual dan identitas online sebagai wujud baru dari khalayak media. Khalayak media berupa komunitas virtual dan identitas online ini terdiri dari penggunan media internet yang berasal dari seluruh dunia yang melampaui batas-batas geografis, budaya dan faktor sosial lainnya. Selain itu, sulit untuk diprediksikan kapan, di mana dan mengapa khalayak media baru ini menggunakan internet, dan internet kini telah diintegrasikan ke dalam aktivitas keseharian yang bersifat personal. Khalayak media jenis ini sekaligus telah menciptakan perbedaan jelas antara "online" dengan "offline", atau antara "virtual" dengan "real". Lebih lanjut, Flew menyebutkan bahwa munculnya komunitas virtual ini merupakan wujud ketidakpuasan terhadap komunitas nyata sehingga individu cenderung memilih terlibat dalam komunitas imajiner tersebut.

Identitas online dalam $\mathrm{CMC}$ ini, selanjutnya mengembangkan kajian baru yang disebut dengan avatar research di mana pendekatan ini menegaskan bahwa identitas-identitas online atau avatars menikmati sebuah ruang interaksi yang netral. Karena tidak ada tanda-tanda yang dapat secara spontan mengindikasikan penampakan, gender, kelas, dan etnisitas dari interlocutor, maka avatars berkomunikasi pada basis yang setara tanpa ada diskriminasi sosial yang menyertai kategori-kategori tersebut (Rahardjo, 2011: 25-26).

\section{PENUTUP}

Khalayak new media dalam dunia postmodernisme, seperti fans/fandom dan komunitas virtual dan identitas online, menciptakan kemungkinan-kemungkinan dinamika identitas khalayak media di mana identitas dapat berubah, meluas, atau menciut. Khalayak ini merupakan jenis khalayak baru yang menggantikan tipe-tipe khalayak dalam perspektif awal tentang khalayak. Hadirnya new media secara tidak langsung ikut memaksa media konvensional untuk menyesuaikan diri dengan teknologi digital.

Media konvensional kini banyak mengadaptasi internet dengan menghadirkan bentuk-bentuk media konvergensi seperti koran digital, radio/TV online, dan sebagainya. Perubahan media ini juga diikuti oleh perubahan pola konsumsi khalayak media lama. Kecenderungan yang terjadi adalah khalayak menjadi lebih aktif melakukan tindakan selektif terhadap media yang akan dikonsumsinya terkait dengan berbagai faktor misalnya kesenangan atau kemudahan. Akses yang mudah dan cepat dalam media baru membuat masyarakat lebih cenderung memilih beranjak dari media konvensional dan secara aktif mengkonsumsi new media. Dalam hal ini, hadirnya new media bisa dikatakan telah memberi kontribusi besar dalam membangkitkan kembali pandangan tentang khalayak aktif.

\section{Daftar Pustaka}

Ang, Ieng. 1996. Living Room Wars: Rethingking Media Audience in a postmodern world. e-book. London: Routledge.

Barker, Chris. 2004. The Sage Dictionary of Cultural Studies. e-book. London: Sage Publications.

Fenton, Natalie (Ed). 2010. New Media, Old News: Journalism \& Democracy in the Digital Age. e-book. London: Sage Publications. 
Flew, Terry. 2005. New Media: An Introduction (2nd Ed). Australia: Oxford University Press.

Hills, Matt. 2002. Fan Cultures. London: Routledge.

McQuail, Denis. 2010. Mass Communication Theory. London: Sage Publications

Ross, Karen \& Nightingale, Virginia (Eds). 2003. Media and Audiences: New Perspective. e-book. UK: Open University Press.

Tester, Keith. 2009. Immortalitas Media. Bantul: Juxtapose.
Toscano, Alberto. Fanaticism: On the Uses of an Idea. e-book. London: Verso.

Turnomo Rahardjo. 2011. Isu-isu Teoritis Media Sosial. Dalam Fajar Junaedi (Ed). Komunikasi 2.0: Teoritisasi dan Implikasi, hal:2-28. Yogyakarta: ASPIKOM. 